В таблице не указаны данные по прочности бетона после выдержки бетонных образцов при температуре $-10^{\circ} \mathrm{C}$ в возрасте 28 суток, так как эксперимент еще продолжается.

В ходе эксперимента выявлен неожиданный результат. Добавка «Кратасол ПФМ», введенная в состав №1, оказывает такое же влияние на бетон как противоморозная добавка, позволяя бетону набирать прочность в условиях отрицательных температур. «Кратасол - ПФМ» - полифункциональная добавка для бетонов, соответствует требованиям ГОСТ 24211-91 «Добавки для бетонов. Общие технические требования»и относится к группе суперпластификаторов и добавкам, повышающим морозостойкость, но не снижающих температуру замерзания.

Как было сказано выше, эксперимент еще не закончен. Следующая цель узнать, на сколько процентов изменится прочность бетона после выдерживания на морозе без прогрева в течении 28 суток по сравнению с прочностью бетонных образцов, выдержанных 28 суток в камере нормального твердения. Еще один этап этой работы является определение потери прочности бетонных образцов после выдерживания их в течении 28 суток на морозе, а затем в нормальных условиях твердения 28 суток, по сравнению с проектной маркой бетона.

Однако можно сделать предварительные выводы: противоморозные добавки «КРИОПЛАСТ СП25-2» и «КРИОПЛАСТ ЭКТРА» действительно не дают бетонным смесям замерзнуть при низких температурах и позволяют набирать прочность до устройства дополнительного прогрева как и указано в технических характеристиках на эти добавки, то есть данные добавки можно использовать на практике.

Список литературы:

1. ГОСТ 10180-2012 «Бетоны. Методы определения прочности по контрольным образцам»

2. ГОСТ 24211-91 «Добавки для бетонов. Общие технические требования».

\title{
Слесарный молоток с механизмом вторичного удара
}

Дегтярев А.В., студент, Северо-Восточный федеральный университет, 2. Якутск E-mail: aytal14031998@gmail.com

Научный руководитель: стариий преподаватель, магистр-инженер Анисимов E.E.

Целью данной работы является усовершенствование слесарного молотка с механизмом вторичного удара для уменьшения отскока и увеличения ударной силы. Для решения поставленной задачи необходимо было решить следующие задачи:

1. Изучить виды столярных и слесарных молотков;

2. Разработать конструкцию молотка со вторичным ударом и изготовить молоток; 
3. Провести испытание ударных свойств молотка;

4. Сделать выводы и рекомендации.

В процессе работы нами использованы следующие методы достижения цели: изучение научно-технической литературы, анализ и сравнение слесарных молотков, испытания.

Новизна молотка с механизмом вторичного удара заключается в отличие от аналогов. Молоток имеет более простую конструкцию для изготовления в домашних условиях. В качестве дополнительного ударного веса имеет цельный груз металлический шарик. Эффективность применения молотка подтверждается испытанием.

Применение такого молотка удобно, практично, уменьшает вероятность порчи материала, экономя при этом время, повышая производительность труда, тем самым приобретет общественно-полезную значимость.

Нами разработан образец слесарного молотка со вторичным ударом. Оборудование конструктивно несложно и можно изготовить в домашних условиях. С его помощью без особых усилий можно пользоваться при забивании гвоздей и при слесарных работах. Данный молоток позволяет значительно облегчить процесс слесарных и столярных работ и уменьшает нагрузку к рукам. Ниже приводятся описания молотка.

Рабочий механизм молотка представляет собой цилиндрическую, глухую, полую металлическую насадку, внутри которой свободно помещен тяжелый металлический шарик. Насадка установлена на срезанной затылочной части молотка. При движении молотка шарик выполняет возвратно - поступательное движение, тем самым гасит сильный отскок молотка от твердых предметов и повышает ударный вес инструмента. Так как при ударе появляется дополнительная динамическая нагрузка из-за движения шарика внутри полости. Для уменьшения шума в хвостовике молотка и затылочной части насадки приклеены резиновые накладки. Вес молотка равен $\mathrm{P}=\mathrm{m}_{\mathrm{m}} \mathrm{g}$, a дополнительная перегрузка $\mathrm{P}=\mathrm{m}_{ш}(\mathrm{~g}+\mathrm{a})$, где

$\mathrm{M}_{\mathrm{M}}=$ масса молотка

$\mathrm{M}_{\mathrm{m}}=$ масса шара

Технические параметры слесарного молотка со вторичным ударом

Головка: материал - специальная сталь марки У7;

Технология: головка - ковка, хвостовик (насадка)- винтовое соединение;

Покрытие - антикоррозионное фосфатирование;

Основной боек: квадратный.

Рукоятка: материал - береза

Вес молотка: 570 г.

Вес шарика: 70 г.

Особенности: полая металлическая насадка со стальным шариком внутри. Доступные ресурсы

- Слесарные молотки - свободная продажа.

- Металлические трубы d 32 мм длиной мм - трубы б/у.

- Металлические шарики d 25 мм - от привода легковых автомобилей.

- Винты d 5 мм метрической резьбой - свободная продажа. 
Таблица 1

Экономический расчет

\begin{tabular}{|c|c|c|c|c|}
\hline No & Материалы & Ед. & Стоимость в руб. & $\begin{array}{c}\text { Общая } \\
\text { сумма } \\
\text { в руб. }\end{array}$ \\
\hline 1 & Слесарные молотки & 1 & 200,00 & \multirow{7}{*}{226,50} \\
\hline 2 & $\begin{array}{l}\text { Металлическая труба d } 32 \text { мм длиной } 65 \\
\text { мм }\end{array}$ & 1 & $6 / y$ & \\
\hline 3 & Металлический шарик d 25 мм & 1 & $6 / y$ & \\
\hline 4 & Винты d 5 мм метрической резьбой & 4 & 20.00 & \\
\hline 5 & Листовой металл & $\begin{array}{l}6,5 \\
\text { см2 }\end{array}$ & 5.00 & \\
\hline 6 & Электрод & 1 & 1.0 & \\
\hline 7 & Потрачено электроэнергии & кВТ & 0.50 & \\
\hline
\end{tabular}

Для изучения и сравнительных анализов отскока после удара обычного слесарного молотка и молотка с механизмом вторичного удара нами произведены ударные испытания. При этом вес слесарного молотка - 560 г, вес слесарного молотка с механизмом вторичного удара - 570 г. (молоток с коробкой - 520 г., металлический шарик - 50 г.)

Удары были произведены с одинаковой высоты и силы по металлическому предмету. Для проведения испытания по определению длины отскока нами выбраны следующие материалы: брус сосновый и стальная плита. В ходе эксперимента взяты следующие показатели:

- длина отскока от сосновой поверхности L, мм

- длина отскока от стальной поверхности L, Mм

Средние значения длин отскоков от поверхностей рассчитаны по формуле:

$\mathrm{L}_{\mathrm{cp}}=\left(\mathrm{L}_{1}+\mathrm{L}_{2}+\mathrm{L}_{3}+\mathrm{L}_{4}\right) / 4$

Результаты данного испытания представлены в таблице 1.

Таблица 2

Показатели отскока молотков от сосновой и стальной поверхностей

\begin{tabular}{|c|c|c|c|c|c|c|c|c|c|c|}
\hline \multirow[t]{2}{*}{ Инструмент } & \multicolumn{4}{|c|}{$\begin{array}{lr}\text { Длина } & \text { отскока от } \\
\text { сосновой } & \text { поверхности } \\
\text { L, мм } & \end{array}$} & \multirow{2}{*}{$\begin{array}{l}\text { Средняя } \\
\text { длина } \\
\text { отскока } \\
\text { от сосно- } \\
\text { вого } \\
\text { бруса } \\
\mathrm{L}_{\mathrm{cp}}, \mathrm{Mм}\end{array}$} & \multicolumn{4}{|c|}{$\begin{array}{lr}\text { Длина } & \text { отскока от } \\
\text { стальной } & \text { поверхности } \\
\text { L, мм } & \end{array}$} & \multirow{2}{*}{$\begin{array}{l}\text { Средняя } \\
\text { длина } \\
\text { отскока } \\
\text { от } \\
\text { сталь- } \\
\text { ной } \\
\text { плиты } \\
\text { L }_{\text {cp }} \text { мм }\end{array}$} \\
\hline & $\mathrm{L}_{1}$ & $\mathrm{~L}_{2}$ & $\mathrm{~L}_{3}$ & $\mathrm{~L}_{4}$ & & $\mathrm{~L}_{1}$ & $\mathrm{~L}_{2}$ & $\mathrm{~L}_{3}$ & $\mathrm{~L}_{4}$ & \\
\hline $\begin{array}{l}\text { Слесарный } \\
\text { молоток }\end{array}$ & 180 & 182 & 181 & 179 & 180.5 & 340 & 335 & 332 & 338 & 336.2 \\
\hline $\begin{array}{l}\text { Слесарный } \\
\text { молоток } \\
\text { механизмом } \\
\text { вторичного } \\
\text { удара }\end{array}$ & 30 & 32 & 31 & 29 & 30.5 & 28 & 30 & 32 & 31 & 30.2 \\
\hline
\end{tabular}



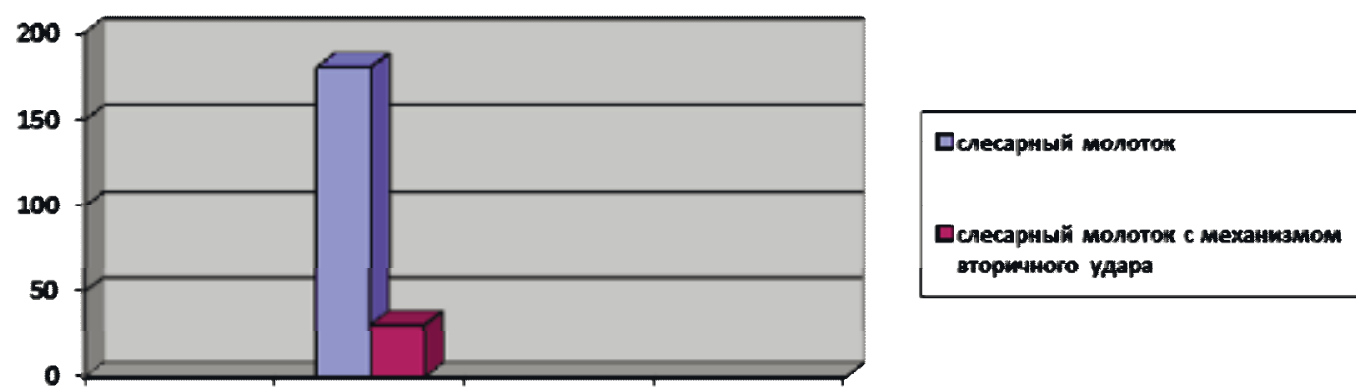

График 1. Средняя длина отскока от соснового бруса $\mathrm{L}_{\mathrm{cp}}$, мм
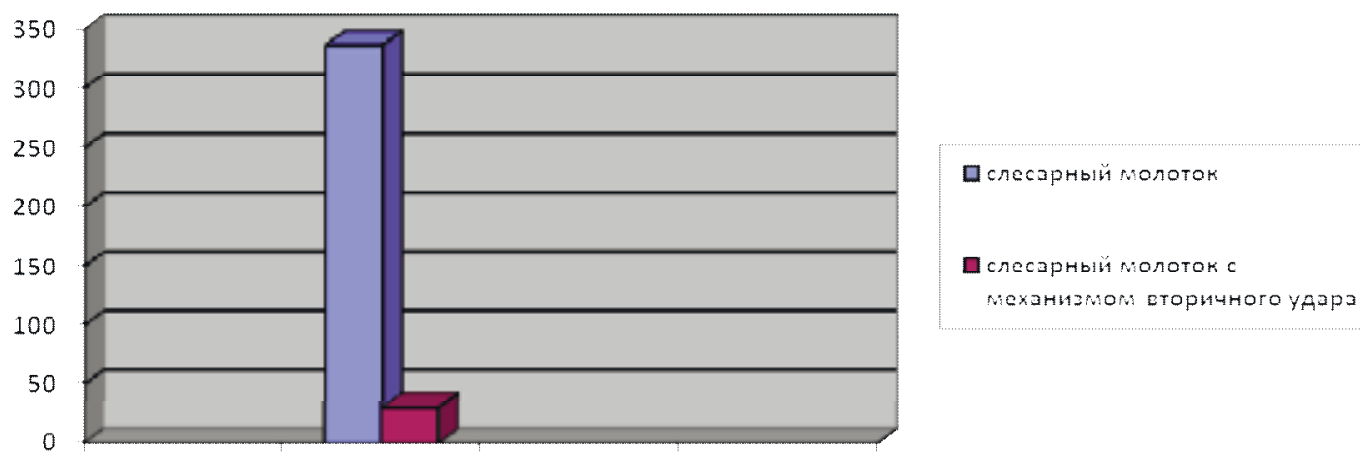

График 2. Средняя длина отскока от стальной плиты $\mathrm{L}_{\mathrm{cp}}$, мм

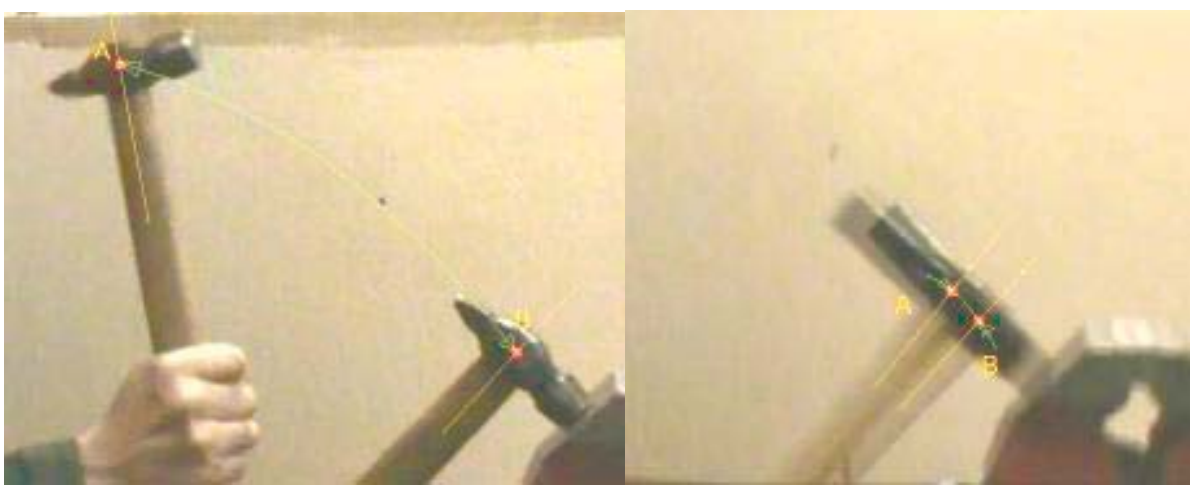

A)

Б)

Рис. 1. Траектория отскока от твердой поверхности. А - обычный молоток, Б слесарный молоток с механизмом вторичного удара

Исследованы ударные свойства усовершенствованного слесарного молотка при выполнении столярных работ.

Таким образом, длина отскока слесарного молотка большая и сильная отдача передается к рукам. При использовании молотка с механизмом вторичного удара длина отскока сокращается в среднем 8,5 раз, уменьшается вибрация, а отдача удара к руке становится минимальной. Удар молотка становится более тяжелой.

\section{Список литературы:}

1. Ростовцев А.Н., Хадточий А.П., Фурманов Ф.А. и др. Справочник по техническому труду: Обработка древесины, металла, электротехнические и другие 
работы: Книга для учителя / Под редакцией А.Н. Ростовцева. - М: Просвещение, 1996 319 с.: ил.

2. Перышкин А.В. Физика. 7 кл.: учеб. для общеобразоват. учреждений/- 12-е изд., доработ.-М.: дрофа. 2008. -192 с.: ил. ISBN 978-5-358-04480-7

3. Рощин Г.И., Самойлов Е.А., Алексеева Н.А. и др. Детали машин и основы конструирования: учеб. для вузов/; под ред. Г.И. Рощина и Е.А. Самойлова. - М.; Дрофа, 2006. - 415, [1]с.: ил. - (Высшее образование).

4. Обработка металла в школьных мастерских: Кн. для учителя. - М.: Просвещение, 1991. - 175 с.: ил.-ISBN 5-09-002661-0.

5. Технология. 5-11 классы: Проектная деятельность учащихся/ авт.-сост. Л.Н. Морозова, Н.Г. Кравченко, О.В. Павлова. - второе издание, стереотип. - Волгоград: Учитель, 2008. -204 с.

6. Черчение. 9 кл.: Учебное пособие для общеобразовательных учреждений. М.: Дрофа. 2003.-144 с.

7. http://www.findpatent.ru/

8. http://strport.ru/

9. http://supertools.com.ua/

\section{Влияние возникновения температурных и отраженных трещин на состояние дорожной одежды}

Кардашевский В.Д., студент, Северо-Восточный федеральный университет, 2. Якутск

E-mail: kardashvadim@mail.ru Макаров Н.М., эксперт дорожного хозяйства 1 категории, ОКК ФКУ УПРДОР «Вилюй», 2. Якутск

Копылов В.Е., инженер, Институт проблем нефти и газа ЯНЦ СО РАН, 2. Якутск

Научный руководитель: ассистент Габымев М.В.

Одним из дефектов дорожной одежды, являются трещины, появляющиеся на поверхности дорожной одежды, наличие трещин значительно уменьшает срок службы дорожной одежды. Основными причинами разрушений покрытия в виде трещин являются: воздействие транспортных нагрузок, перепады температур от положительных к отрицательным, низкие отрицательные температуры, трещины и швы в нижележащих слоях, различие теплофизических свойств материалов слоев смежных покрытий, неравномерное уплотнение земляного полотна и слоев дорожной одежды, образование пучин, сопровождающееся возникновением сетки трещин в дорожной одежде.

В зависимости от природы трещинообразование приобретает различные формы: 